Ege Tıp Dergisi / Ege Journal of Medicine 2021; 60 (2): 105-112

\title{
Pandemi günlerinde kronik tıbbi hastalığı olan psikiyatrik takipteki çocuk ve gençlerin uyum süreci ve hastalık belirtileri
}

\author{
Compliance process and disease symptoms of children and adolescent with \\ chronic medical disease in the pandemi days
}

\begin{tabular}{|c|c|c|c|}
\hline Birsen Şentürk Pilan (D) & Serpil Erermiş (D) & Reyhan Çalışan & Begüm Yuluğ \\
\hline Sibel Helin Tokmak & Sezen Köse & Burcu Özbaran & Tezan Bildik \\
\hline
\end{tabular}

Öz

Amaç: Bu çalışmada kronik tıbbi hastalığı olan psikiyatrik takipteki çocuk ve gençlerin pandemi ile ilgili uyum süreci ve psikiyatrik belirtilerindeki değişikliklerin Teletıp uygulaması ile değerlendirilmesi amaçlanmıştır.

Gereç ve Yöntem: Çalışmaya, Konsültasyon Liyezon Polikliniği'nde takipli, 0-18 yaş arasındaki olgular dahil edilmiştir. Olgular randevularının oldukları gün ve saatlerde, Teletıp yolu ile aranarak ebeveyn ve kendileri ile psikiyatrik görüşme yapılıp son durumları değerlendirilmiştir. Pandemi ile ilgili uyum sürecini araştırmak amacıyla araştırmacılar tarafından hazırlanan anket soruları olgu ve ailelerine sorulmuş, cevapları olgu veri formuna kaydedilmiştir. Olguların pandemi öncesi Klinik Global İlenim (KGi) ölçeği puanları dosyalarındaki bilgilere göre, pandemi dönemindeki KGi puanları da telefonla yapılan görüşme sonucuna göre kaydedilmiştir.

Bulgular: Çalışmamıza katılan olguların \%49'u $(n=25)$ kız, \%51'i $(n=26)$ ise erkektir. En sık görülen kronik tıbbi hastalıklar nörolojik $(\% 21,6, n=11)$ ve metabolik-genetik $(\% 21,6, n=11)$ hastalıklar olarak tespit edilmiştir. Olgularımızda pandemi öncesi tespit edilen psikiyatrik tanılarda birinci sırada Dikkat Eksikliği/ Aşırı Hareketlilik Bozukluğu $(\% 35,3)$, ikinci sırada Depresyon Bozuklukları $(\% 17,6)$ ve Anlıksal Gelişimsel Bozukluk (Ağır Olmayan) $(\% 17,6)$ gelmektedir. Olguların pandemi öncesi KGI puanı 2,62 $\pm 0,59$, pandemi sürecindeki KGI puanı 2,90 $\pm 0,80$ olarak değerlendirilmiştir. Aradaki fark istatistiksel olarak anlamlıdır $(p=0,003)$. Evde sağlık çalışanı olup olmaması ve yakınlarında hastalıktan etkilenen birey olup olmaması ile KGI puanı arasında anlamlı bir fark saptanmamıştır $(p>0,05)$.

Sonuç: Çalışmamız kronik tıbbi hastalığı olan ve psikiyatrik takipteki olgularda, pandemi sürecinde ruh sağlığının olumsuz etkilendiğini, sinirlilik ve kaygı gibi belirtilerde artma olduğunu ve immatür davranışlar, uyku düzeninde değişiklik gibi yeni ruhsal belirtilerin eklendiğini göstermesi bakımından önemlidir.

Anahtar Sözcükler: Covid-19, pandemi, çocuk ve ergen, kronik tıbbi hastalık, ruh sağlığı, Teletıp.

Bu çalışma, 18-20 Aralık 2020 tarihlerinde düzenlenmiş olan 56. Ulusal Psikiyatri Çevrimiçi Kongresi'nde sözlü bildiri olarak sunulmuştur.

\section{ABSTRACT}

Aim: In this study, it was aimed to evaluate the changes in psychiatric follow-up process and psychiatric symptoms of children and adolescents with chronic medical diseases by telemedicine.

\footnotetext{
Sorumlu yazar: Birsen Şentürk Pilan

Ege Üniversitesi Tıp Fakültesi Hastanesi Çocuk ve Ergen Ruh

Sağlığı ve Hastalıkları Anabilim Dalı, İzmir, Türkiye

E-posta: drbirsensenturk@yahoo.com

Başvuru Tarihi: 11.12.2020 Kabul Tarihi: 12.01.2021
} 
Materials and Methods: In this study, the cases between 0-18 years old who were followed up at the Consultation liaison outpatient clinic were included. The patients were contacted via Telemedicine on the days and hours of their appointments and their psychiatric interviews were made with their parents and they were evaluated. Questionnaire prepared by the researchers were asked to the patients and their families to investigate the compliance process related to the pandemic and their answers were recorded in the case data form. According to the information in the Clinical Global Impression (CGI) scale scores of the cases before the pandemic, the CGI scores in the pandemic period were also recorded according to the results of the telephone interview.

Results: In our study, $49 \%(n=25)$ of the cases were girls and $51 \%(n=26)$ were boys. The most common chronic medical diseases were identified as neurological $(21,6 \%, n=11)$ and metabolicgenetic $(21,6 \%, n=11)$ diseases. In the psychiatric diagnoses found in our cases, Attention Deficit/ Hyperactivity Disorder (35,3\%) was in the first, Depression Disorders (17,6\%) and Mild Intellectual Disability $(17,6 \%)$ were in the second place. The CGI score of the cases before the pandemic was $2,62 \pm 0,59$, and the CGI score in the pandemic process was evaluated as $2,90 \pm 0,80$. The difference is statistically significant $(p=0,003)$. There was no significant difference between the presence of a health worker at home and the presence of a person affected by the disease and the CGI score ( $p>$ 0,05).

Conclusion: Our study is important in terms of showing that mental health is negatively affected during the pandemic process, in patients with chronic medical diseases and psychiatric follow-up, there is an increase in symptoms such as nervousness and anxiety, and new mental symptoms such as immature behaviors and changes in sleep patterns are added.

This study was presented as an oral presentation at the 56th National Psychiatry Online Congress organized on 18-20 December 2020.

Keywords: Covid-19, pandemic, child and adolescent, chronic medical disease, mental health, telemedicine.

This study was presented as an oral presentation at the 56th National Psychiatry Online Congress held on 18-20 December 2020.

\section{GíRiş}

Illk kez Çin'in Wuhan eyaletinde görülen, daha sonra da birçok ülkeye hızlı bir şekilde yayılmış olan coronavirus ailesinden SARS-CoV 2 (Ağır Akut Solunum Sendromu Virüsü 2), akut solunum yetmezliği ile giden COVID-19 (Coronavirus Disease 2019) tablosuna yol açmış ve Dünya Sağlık Örgütü (DSÖ) tarafından 11.03.2020 tarihinde pandemi olarak ilan edilmiştir (1). Hastalık esas olarak damlacık yoluyla, enfekte bir insanın öksürüğü, hapşırığı veya solunum yolu sekresyonlarının bir başka insanın mukoz membranları ile teması sonucu bulaşmaktadır (2). Bu gün için virüs atıım süresi ve bulaştırıcılık süresi tam olarak bilinmediği için kişilerin izolasyon önlemleri ile kendilerini korumaları gerekmektedir $(3,4)$.

Salgının ilk dönemlerinde çocuk hasta sayısı oldukça az olduğu için çocukların salgına duyarlı olmadığı düşünülmüş; ancak ev içinde yetişkinlerin ve çocukların bir arada bulunması çocuk vakaların sayısını da yavaş yavaş artırmıştır. Çocukların klinik belirtilerinin ateş, öksürük gibi yetişkinlerin belirtilerine benzer olduğu bazen ise burun akıntısı, ishal gibi nispeten hafif semptomların görüldüğü tespit edilmiştir (5).

Çocuk ve erişkinlerin altta yatan kronik hastalıkları farklı olsa da COVID-19'a hassasiyetlerinin benzer olduğu görülmüştür. Erişkinlerde kardiyovasküler hastalıklar, diyabet, kronik akciğer hastalıkları, hipertansiyon ve kanser gibi bozukluklar ölüm hızını arttırmaktadır. Çocuklarda ise diyabet, adrenal yetmezlik, kronik akciğer hastalıkları, kanserler, immün yetmezlikler, kronik böbrek yetersizliği ve nörolojik bozukluklar gibi ek hastalıklar COVID19'a bağlı ciddi hastalık ve ölüm tehlikesini arttırabilmektedir (6).

Kronik hastalık, 6 ay ve daha uzun süredir devam eden, çocuk ve ergenin yaşamında değişikliğe yol açan tıbbi durum olarak tanımlanmaktadır. Çocukluk döneminde kronik hastalık yaygınlığı \%10-20 olarak bildirilmekte ve bunların \%10'unun 
ağır düzeyde olduğu belirtilmektedir (7). Çocuklukta kronik tıbbi hastalık varlığı, daha sonra psikiyatrik bozukluk ortaya çıkması açısından önemli bir risk etkeni olarak görülmektedir (8). Pandemi ile birlikte, kronik tıbbi hastalıklarda psikiyatrik hastalığa yatkınlık riskine, pandeminin etkilerinin getireceği ruhsal belirtilerde artış ya da yeni belirtilerin ortaya çıkma riski de eklenmiştir.

Pandemi dönemiyle birlikte çocukların ve ailelerin yaşam şekillerinde değişiklikler başlamıştır. Ülkemizde alınan önlemler kapsamında, 23.03.2020 tarihi itibariyle okullar kapatılmış olup uzaktan eğitime geçilmiştir. 04.04.2020 tarihinde ise 20 yaş altına sokağa çıkma yasağı getirilmiştir. Çocuklar evden eğitsel desteklerini sürdürürken bazı aile bireyleri ise işlerini evden yürütmek durumunda kalmış bu sebeple çocuk ve ailelerin rutinleri değişmiştir. Bu durum yeni koşullara uyum süreci ve bu süreçte ortaya çıkabilecek zorlukları da beraberinde getirmiştir. Pandemi sürecinde tedaviyi sürdürebilme ve psikolojik destek açısından tele psikiyatrinin önemli bir rol oynadığı görülmüştür (9). Üniveristemizde de salgın önlemleri kapsamında Koronavirüs (COVID-19) Salgını Koordinasyon Komisyonunun 18/03/2020 tarihli toplantısında alınan karar gereği poliklinik hizmetlerinin Teletıp çerçevesinde devam ettirilmesi uygun görülmüştür.

Teletıp kelime anlamıyla mesafeden bağımsız olarak sağlık hizmeti sunumunun bilgi iletişim teknolojileri kullanılarak gerçekleştirilmesi anlamına gelir. Uygulamalar video konferans, email, web tabanlı uygulamalar veya telefon tabanlı uygulamalar şeklinde olabilir (10).

COVID-19 için yüksek mortalite riskine sahip olan onkolojik ve kronik tıbbi hastalığı olan hastaların takipleri, tedavi süreçlerinin kontrolü, semptomlarının yönetimi ve psikososyal yönden desteklenmeleri amacıyla Teletıp hem hastalar hem de hekimler tarafından hızlıca benimsenmiştir (11).

Ruh sağlığı ve çocuk ruh sağlığı hizmetlerinin pandemi nedeniyle dünyanın birçok yerinde kısıtlandığı ve sekteye uğradığı bilinmektedir ancak bu durumun etkileri konusunda yapılan bilimsel araştırma sayısı kısıtıdır $(12,13,14)$. Bu çalışmada kronik tıbbi hastalığı olan psikiyatrik takipteki çocuk ve gençlerin pandemi ile ilgili uyum süreci ve psikiyatrik belirtilerindeki değişikliklerin Teletıp uygulaması ile değerlendirilmesi amaçlanmıştır.

\section{GEREÇ ve YÖNTEM}

Çalışmamıza, üniversitemizin Çocuk ve Ergen Ruh Sağlığı ve Hastalıkları Anabilim Dalı Konsültasyon Liyezon Polikliniğinde takip edilen, 0-18yaş arasında ve çalışmaya katılmayı kabul eden olgular dahil edilmiştir. Üniversitemizin Çocuk ve Ergen Ruh Sağlığı Konsültasyon Liyezon birimi hem hastanede yatan hem de ayaktan gelen hastalara konsültasyon hizmeti vermekte, yatan hastalardan psikiyatrik bir bozukluk tespit edilen olguları da taburculuk sonrası poliklinik takibine almaktadır.

Olgular randevularının oldukları gün ve saatlerde, Teletıp yolu ile aranarak ebeveyn ve kendileri ile görüşme yapılıp son durumları değerlendirilmiştir. Teletıp yöntemi olarak olgu ve aileleri ile telefon aracılığı ile görüşülmüştür. Teletıp ile 60 olguya ulaşımış, ancak çalışmaya katılmaya gönüllü olan 51 olgu çalışmaya dahil edilmiştir. Görüşme sırasında psikiyatrik belirti değerlendirmesi yapılmış, ilaç etki ve yan etkileri, günlük rutin sorgulanmış, işlevsellik değerlendirilmiş, tedavi planlanmış ve psikososyal açıdan destek verilmiştir. Pandemi ile ilgili uyum sürecini araştırmak amacıyla araştırmacılar tarafından hazırlanan anket soruları olgu ve ailelerine sorulmuş, cevapları olgu veri formuna kaydedilmiştir. Her olgu ve ailesi ile ortalama 30 40 dakika Teletıp yolu ile görüşme yapılmıştır. Olguların pandemi öncesi Klinik Global İzlenim (KGi) ölçeği puanları dosya taraması sırasında retrospektif olarak skorlanarak, DSM 5'e göre konulmuş olan psikiyatrik tanıları dosyalarındaki bilgilere göre, pandemi dönemindeki KGi puanları da telefonla yapılan görüşme sonucuna göre kaydedilmiştir.

Çalışmaya katılmayı kabul eden olgu ve ebeveynine çalışma hakkında ayrıntılı bilgi verilerek online olarak (whatsapp ya da mail yolu ile) çalışma için onam alınmıştır. T.C. Sağlık Bakanlığı Sağlık Hizmetleri Genel Müdürlüğü Bilimsel Araştırma Kurulu'ndan onay alındıktan sonra (09.05.2020), etik kurul onayı, Üniversitemizin Tıbbi Araştırmalar Etik Kurulu'ndan alınmıştır (Karar no:20-5.2T/37, Tarih:29.05.2020).

\section{Değerlendirme Araçları}

Anket: Yazarlar tarafından hazırlanmıştır. Hem hastaya dair bilgileri (yaş, tanı, kullandığı ilaçlar, kiminle yaşadığı), hem de pandemi ile ilgili bilgileri (evde sağlık çalışanı olup olmadığı, evde ya da yakın çevrede salgından etkilenen birey olup olmadığı, günlük rutini ile ilgili sorular, salgınla ilgili haberleri izleyip izlemediği, uyku ve 
beslenmede değişiklik olup olmadığı, psikiyatrik belirtilerde değişiklik olup olmadığı vb.) içeren maddelerden oluşmaktadır.

Klinik Global İzlenim Ölçeği (KGi): Herhangi bir hastalığın şiddeti ile hastalık belirtilerindeki düzelmeyi genel olarak değerlendiren bir ölçüm aracıdır. Ölçeği kullanan klinisyen, söz konusu hastalıkla ilgili bilgi ve deneyimlerinin ışığında, hastalığın şiddeti ile belirtilerdeki düzelmenin derecesini, 1'den 7'ye uzanan likert tipi bir derecelendirme üzerinde (1- normal, hasta değil, 2- sınırda hasta, 3- hafif derecede hasta, 4- orta derecede hasta, 5- belirgin derecede hasta, 6ileri derecede hasta, 7- en ileri derecede hasta) değerlendirir (15).

\section{İstatistiksel Analiz}

Verilerin istatiksel analizi, SPSS 25 paket programı kullanılarak yapılmıştır. Hastaların sosyodemografik özellikleri, başvuru yakınmaları, psikiyatrik tanı dağılımları, anket soruları tanımlayıcı istatistiksel analiz yöntemleri-frekans analizleri ile değerlendirilmiştir. Veriler sayı ve yüzde şeklinde özetlenmiştir. Tüm analizler için $p$ değerinin 0,05 'in altında olması istatistiksel olarak anlamlı kabul edilmiştir.

\section{BULGULAR}

Çalışmamıza katılan olguların \%49'u $(n=25) \mathrm{kız}$, $\% 51$ 'i $(n=26)$ ise erkektir. Katılımcıların ortalama yaşı $11,35 \pm 4,25$ 'tir. Katılımcıların aile yapıları incelendiğinde; \%78,4'ünün çekirdek aile, $\% 11,8^{\prime}$ inin geniş aile, \%6,9'unun parçalanmış aile, \%1'inin aile büyükleri şeklinde yaşadıkları görülmüştür. Çalışmaya katılan hastaların \%7,8'i $(n=4)$ evde sağlık çalışanı ile birlikte yaşamaktadır. Yakın çevresinde salgından etkilenen tanıdığı olan olgu \%5,9 ( $n=3)$ 'dur. Olguların \%94,1 $(n=48)$ 'de ise yakın çevresinde salgından etkilenen kişi bulunmamaktadır. Katılımcılarda en sık görülen kronik tıbbi hastalıklar nörolojik $(\% 21,6, n=11)$ ve metabolikgenetik $(\% 21,6, n=11)$ hastalıklar olarak tespit edilmiştir. Diğer kronik tıbbi hastalıklar ve sosyodemografik veriler Tablo-1'de özetlenmiştir.

Tablo-1. Sosyodemografik veriler.

Olgu Yaşı (Yıl)
$\circ \quad K I z$
$\circ \quad$ Erkek

\section{Olguların Cinsiyeti}

- KIz

- Erkek

\section{Aile özelliği}

$\begin{array}{ll}\circ & \text { Çekirdek aile } \\ \circ & \text { Parçalanmış aile } \\ \circ & \text { Geniş aile } \\ \circ & \text { Diğer }\end{array}$

Evde Sağlık Çalıșanı

$$
\begin{array}{ll}
\circ & \text { Var } \\
\circ & \text { Yok }
\end{array}
$$

\section{Salgından Etkilenen Yakını}

$$
\begin{array}{ll}
\circ & \text { Var } \\
\circ & \text { Yok }
\end{array}
$$

\section{Kronik Tıbbi Hastalık}

Nörolojik

Metabolik-genetik

Endokrinolojik

Solunum-alerii

Onkolojik Hastalık

Dermatolojik

Kardiyolojik

Nefrolojik

Diğer

\section{$11,35 \pm 4,25$ \\ $12.38 \pm 3,52$ \\ $10.38 \pm 4,70$ \\ n (\%) \\ 25 (49) \\ 26 (51) \\ $\underline{\text { n }(\%)}$ \\ $40(78,4)$ \\ $4(6,9)$ \\ $6(11,8)$ \\ 1 (1) \\ n (\%) \\ $4(7,8)$ \\ $47(92,2)$}

n (\%)

$3(5,9)$

$48(94,1)$

n (\%)

$11(21,6)$

$11(21,6)$

$8(15,7)$

$5(9,8)$

$5(9,8)$

$4(7,8)$

$2(3,9)$

$2(3,9)$

$3(5,9)$ 
Tablo-2. Pandemi dönemindeki değişiklikler.

\begin{tabular}{ccc}
\hline Günlük Rutin & $\underline{\mathbf{n}(\%)}$ \\
\hline & Kitap okuma & $11(26)$ \\
$\circ$ & Bilgisayar oyunu & $16(31,4)$ \\
$\circ$ & Televizyon & $31(60,8)$ \\
$\circ$ & Sosyal Medya & $30(58,8)$ \\
$\circ$ & Ders & $20(32,2)$ \\
$\circ$ & Hobi & $10(19,9)$ \\
$\circ$ & Aile ile birlikte vakit & $33(74,5)$ \\
Sayı ve yüzdeler her etkinlik için ayrı ayrı hesaplanmıştır. & $\underline{\mathbf{n}(\%)}$ \\
$\underline{\text { İstah }}$ & & $13(25,5)$ \\
$\circ$ & Artma & $7(13,7)$ \\
$\circ$ & Azalma & $31(60.8)$ \\
& Değişiklik yok & $\underline{\mathbf{n}(\%)}$ \\
$\underline{\text { Uyku }}$ & & $6(11,8)$ \\
$\circ$ & Artış & $2(3,9)$ \\
$\circ$ & Azalma & $25(49)$ \\
$\circ$ & Farklılık yok & $18(35,3)$ \\
\hline
\end{tabular}

Tablo-3. Pandemi öncesi psikiyatrik tanılar.

\begin{tabular}{lcc}
\hline Psikiyatrik Tanı & N & $\%$ \\
\hline Dikkat Eksikliği/ Aşırı Hareketlilik Bozukluğu & 18 & 35,3 \\
Depresyon Bozuklukları & 9 & 17,6 \\
Hafif Düzeyde Zihinsel Yetersizlik & 9 & 17,6 \\
Anksiyete Bozuklukları & 6 & 11,8 \\
Davranım Bozukluğu & 4 & 7,8 \\
Otizm Açıımı Kapsamında Bozukluk & 3 & 5,9 \\
Iletişim Bozuklukları & 3 & 5,9 \\
Özgül Öğrenme Bozukluğu & 1 & 2 \\
Orta Düzeyde Zihinsel Yetersizlik & 1 & 2 \\
Dışa Atım Bozuklukları (Enürezis) & 1 & 2 \\
\hline
\end{tabular}

*Bazı olgularda birden fazla eş tanı bulunmaktadır. Sayı ve yüzdeler her tanı için ayrı ayrı hesaplanmıştır.

Olguların \%21,6'sının (n=11) kitap okuyarak, $\% 31,4$ 'ünün $\quad(n=16)$ bilgisayar oynayarak, $\% 60,8$ 'inin $(n=31)$ televizyon izleyerek, \%58,8'inin $(n=30)$ sosyal medyada, \%32,2'sinin $(n=20)$ ders çalışarak, \%19,9'unun $(n=10)$ hobileri ile uğraşarak, \%74,5'inin $(n=33)$ ailesi ile birlikte vakit geçirdiği tespit edilmiştir. Olguların pandemi dönemindeki günlük rutinleri, iştah ve uyku değişiklikleri Tablo-2'de özetlenmiştir.
Olgularımızda pandemi öncesi tespit edilen psikiyatrik tanılarda birinci sırada Dikkat Eksikliği/Aşırı Hareketlilik Bozukluğu (\%35,3), ikinci sırada Depresyon Bozuklukları $(\% 17,6)$ ve Anlıksal Gelişimsel Bozukluklar (Ağır Olmayan) $(\% 17,6)$ gelmektedir. Diğer psikiyatrik tanı sıklıkları Tablo-3'te özetlenmiştir.

Olguların pandemi dönemi öncesi ve sonrası psikiyatrik bulgularındaki değişiklikler 
sorulduğunda \%33,3 $(n=17)$ olguda belirtilerde artma (sinirlilik, kaygı), \%15,7 $(\mathrm{n}=8)$ olguda belirtilerde azalma (mutsuzluk, iştah sorunları) $\% 9,8(n=5)$ olguda daha önce olmayan belirtilerin (immatür davranışlar, uyku düzeninde değişiklik) ortaya çıktığı bildirilmiştir. Olguların \%39,2'sinin $(n=20)$ mevcut psikiyatrik şikayetlerinde herhangi bir değişiklik bildirilmemiştir.

Olguların pandemi öncesi KGI puanı 2,62 $\pm 0,59$, pandemi sürecindeki KGI puanı $2,90 \pm 0,80$ olarak değerlendirilmiştir. Aradaki fark istatistiksel olarak anlamlıdır $(p=0,003)$. Evde sağlık çalışanı olup olmaması ve yakınlarında hastalıktan etkilenen birey olup olmaması ile $\mathrm{KGI}$ puanı arasında anlamlı bir fark saptanmamıştır $(p>0,05)$.

Olguların kullandıkları ilaçlara bakıldığında, $\% 13,7 \quad(n=7)$ 'si Seçici Seratonin Geri Alım İnhibitörü (SSGI), \%13,7 (n=7)'si antipsikotik, $\% 11,8(n=6)$ 'i stimulan, \%2 $(n=1)$ 'si diğer ilaçları kullanmaktadır. Hastaların bir kısmı çoklu psikiyatrik ilaç kullanmaktadır; \%2'si $(n=1)$ antipsikotik ve SSGI, \%2'si $(n=1)$ antipsikotik ve stimulan, \%2'si ( $n=1)$ antipsikotik, SSRI ve benzodiazepin kullanmaktadır. Çalışmaya katılanların \%49'u $(n=25)$ psikiyatrik ilaç kullanmamaktadır.

İmkân olsa en çok yapmak istedikleri üç şey sorulduğunda ise \%43,1 ( $n=22)$ 'i sokağa çıkmak istediklerini belirtmiştir. Olguların \%35,2 $(n=18)$ 'si bir istek belirtmezken, \%11,8 (n=6)'i okula gitmek, \%9,9 (n=5)'u arkadaşlarıyla vakit geçirmek istediklerini belirtmiştir.

\section{TARTIŞMA}

Tüm dünyayı etkisi altına alan COVID-19 salgınının dramatik etkisi çocuk ve gençleri de etkilemiştir. Çocuklar da bu dönemde erişkinlerde olduğu gibi korkular, belirsizlikler, fiziksel ve sosyal izolasyon ile ilgili zorluklar yaşarlar. Tepkilerini ve duygularını anlamak onların intiyaçlarını doğru bir şekilde karşılamak için çok önemlidir. Birçok çalışma, çocuklarda olumsuz olaylara bağlı psikolojik stresin zararlı etkilerini belgelemektedir. Anksiyete, depresyon, sosyal etkileşim bozukluğu ve iştah azalması yaygın olarak bildirilen belirtilerdir $(16,17)$.

Bizim çalışmamızda olguların ortalama yaşı $11,35 \pm 4,25$ 'tir. Yazında pandemi dönemlerinde okul çağındaki çocuklarda korku ve kaygıda belirgin artış, kardeşlerle sorun yaşama, huzursuzluk, saldırganlık, psikosomatik şikayetler, odaklanmada zorluk, uyku sorunları ve sosyal çekilme gibi davranışların gözlenebileceğine işaret edilmektedir $(18,19)$. Olgularımızın \%49'unda uyku düzeninde değişiklikler olduğu tespit edilmiş olup yazınla uyumludur.

Pandemi dönemi ile birlikte kronik tıbbi hastalığı olan çocuklar sadece Covid-19 enfeksiyonu açısından değil, kronik hastalıklarının ve eşlik eden psikiyatrik hastalıklarının tedavisinin aksaması ile de tehlike altına girmiştir. Çalışmaya katılan olgularımızda tespit edilen psikiyatrik tanılardan birinci sırada Dikkat Eksikliği/ Aşırı Hareketlilik Bozukluğu $(\% 35,3)$, ikinci sırada Depresyon Bozuklukları $(\% 17,6)$ ve Anlıksal Gelişimsel Bozukluk (Ağır Olmayan) (\%17,6) gelmektedir. Kronik tıbbi hastalık ve psikiyatrik hastalıklar bir arada olduğunda çocukların tedaviye uyumu zorlaşmaktadır. Dikkat eksikliği hiperaktivite bozukluğu (DEHB), öğrenme bozukluğu, zekâ geriliği gibi ek tanıların varlığı, çocuğun hastalığı anlamasını etkilemekte ve tedavi uyumunu bozabilmektedir (20). DEHB tanılı olgularımızın yarısında epilepsi tanısı da eşlik etmekte olduğu için stimulan tedavisine onay verilmemiştir. $\mathrm{Bu}$ da uyumu bozan etkenlerden biri olarak değerlendirilmiştir.

Pandemi dönemi öncesi ve sonrası psikiyatrik bulgularındaki değişiklikler sorulduğunda $\% 43,1$ 'de $(n=23)$ olguda belirtilerde artma ya da yeni belirtilerin ortaya çıktığı, \%39,2'sinin $(n=20)$ mevcut psikiyatrik şikayetlerinde herhangi bir değişiklik olmadığı tespit edilmiştir. Olguların pandemi öncesi KGi puanı 2,62 $\pm 0,59$, pandemi sürecindeki $\mathrm{KGI}$ puanı $2,90 \pm 0,80$ olarak değerlendirilmiştir. Aradaki fark istatistiksel olarak anlamlıdır. Salgın nedeniyle oluşabilecek psikolojik etkileri önleme ve müdahale noktasında salgından daha fazla olumsuz etkilenebilecek olan kronik tıbbi hastalığı olan çocuklar, ergenler, psikiyatrik takipte olan çocuk ve ergenler gibi yüksek risk grubundakilerin belirlenmesi ve desteklenmesi önemlidir. Müdahale ve tedavi süreçlerinde yüz yüze, çevrim içi ve medya (televizyon, internet) gibi birden fazla kanaldan ulaşıımasının daha etkili sonuçlar sağlayabileceği belirtilmektedir (21).

Çin'in Shaanxi Eyaleti'nde yerel yetkililer tarafından, pandemi sürecinin başlangıcında (Şubat 2020) yapılan bir ön çalışmada, 3-18 yaş arası toplam 310 çocuğun (168 kız, 142 erkek) psikolojik ve davranışsal sorunlar yaşayıp yaşamadıkları çevrimiçi bir anket kullanılarak değerlendirilmiş, elde edilen sonuçlar, 3-6 yaş çocukların daha büyük çocuklardan daha fazla, 
aile üyelerinin enfeksiyona yakalanma korkusu yaşadıkları, 6-18 yaş arası çocukların dikkatsizlik ve sürekli sorgulama belirtileri gösterdikleri, tüm yaş grubundaki çocukların yaygın olarak dikkat dağınıklığı ve sinirliliğin yanı sıra, sarılmaktan ve salgın hakkında soru sormaktan kaçındıklarını ortaya koymuştur (22).

Çalışmamızda olguların, \%31,4'ünün $\quad(n=16)$ bilgisayar oynayarak, \%60,8'inin ( $n=31)$ televizyon izleyerek, \%58,8'inin $(n=30)$ sosyal medyada, \%32,2'sinin $(n=20)$ ders çalışarak, $\% 19,9$ 'unun $(n=10)$ hobileri ile uğraşarak, $\% 74,5$ 'inin ( $n=33)$ ailesi ile birlikte vakit geçirdiği tespit edilmiştir. Çin'deki bir çalışmada medya eğlencesi, okuma ve fiziksel egzersiz büyük ölçüde aileler tarafından çocuklarının sıkıntısını hafifletmek ve yaşadıkları olumsuz durumla ilgili endişelerini gidermek için başarılı bir şekilde kullanıldığı bildirilmiştir (22).

\section{SONUÇ}

Ülkemizde, pandemi sürecinde kronik tıbbi hastalığı ve eşlik eden psikiyatrik hastalığı olan çocuk ve ergenlerde Teletıp yöntemi ile müdahale ve tedaviye örnek bir çalışmaya rastlanmamıştır. Çalışmamız kronik tıbbi hastalığı olan ve psikiyatrik takipteki olgularda, pandemi sürecinde ruh sağlığının olumsuz etkilendiğini, sinirlilik ve kaygı gibi belirtilerde artma olduğunu ve immatür davranışlar, uyku düzeninde değişiklik gibi yeni ruhsal belirtilerin eklendiğini göstermesi bakımından önemlidir. Bu süreçte ruh sağlığı hizmetlerinin sürdürülmesi hastalıkların kontrol ve tedavisi yanında yaşam kalitesi ve işlevsellik açısından da önem kazanmaktadır.

\section{Kısıtılıklar}

Çalışmamızın en büyük kısıtılıkları kesitsel olması ve örneklem sayısının azlığıdır. Teletıp görüşmeleri telefon ile yapılmış olduğundan hastaların, ebeveynlerin, yüz ifadesi, jest ve mimiklerinin görülememesi bir kısıtlılık olarak söylenebilir.

Çıkar çatışması: Yazarlar çıkar çatışması beyan etmemişlerdir.

\section{Kaynaklar}

1. World Health Organization. Who Announced COVID-19 Outbreak A Pandemic. 12.03.2020.

2. Yuen KS, Ye ZW, Fung SY, Chan CP, Jin DY. SARS-CoV-2 and COVID-19: The most important research questions. Cell and Bioscience. 2020; 10 (1). doi:10.1186/s13578-020-00404-4.

3. World Health Organization. Infection prevention and control during health care when novel coronavirus (nCoV) infection is suspected, 25.01.2020.

4. T.C. Sağlık Bakanlığı Halk Sağlığı Genel Müdürlüğü COVID-19 (SARS-CoV-2 Enfeksiyonu Rehberi) Bilim Kurulu Çalışması. 14.04.2020. Ankara.

5. Xia W, Shao J, Guo Y, Peng X, Li Z, Hu D. Clinical and CT features in pediatric patients with COVID-19 infection: Different points from adults. Pediatr Pulmonol. 2020; 55 (5): 1169-1174. doi:10.1002/ppul.24718.

6. Evliyaoğlu O. Children with chronic disease and COVID-19. Turk Pediatri Ars 2020; 55 (2): 93-4.

7. Wallender JL, Varni JW. Effects of pediatric chronic physical disorder on child and family adjustment. J Child Psychol Psychiatry 1998; (39): 29-46.

8. Erdoğan A, Karaman MG. Kronik ve ölümcül hastalığı olan çocuk ve ergenlerde ruhsal sorunların tanınması ve yönetilmesi. Anadolu Psikiyatri Derg 2008; (9): 244-252.

9. Fegert JM, Vitiello B, Plener PL, Clemens V. Challenges and burden of the Coronavirus 2019 (COVID-19) pandemic for child and adolescent mental health: a narrative review to highlight clinical and research needs in the acute phase and the long return to normality Child Adolesc Psychiatry Ment Health. 2020;14. doi:10.1186/s13034-020-00329-3).

10. Özge A, Uludüz D. Pandemi döneminde öne çıkan bir gerçek: Teletıp uygulamaları. Uludüz D, Özge A, editörler. Nörolojik Bilimler ve COVID-19. 1. Baskı. Ankara: Türkiye Klinikleri; 2020. p.79-85.

11. Tanrıverdi Ö. COVID 19 pandemisi ve teletıp. Yalçın Ş, Özet A, editörler. Kanser ve COVID- 19 Pandemisi. 1. Baskı. Ankara: Türkiye Klinikleri; 2020. p.211-8.

12. Li W, Yang Y, Liu Z-H, et al. Progression of Mental Health Services during the COVID-19 Outbreak in China. Int J of Biol Sci. 2020; 16 (10): 1732-38. doi:10.7150/ijbs.45120. 
13. Liu S, Yang L, Zhang C, et al. Online mental health services in China during the COVID-19 outbreak. The Lancet Psychiatry. 2020; 7 (4): 17-8. doi:10.1016/S2215-0366(20)30077-8 ;13.

14. Yao $\mathrm{H}$, Chen JH, Xu YF. Patients with mental health disorders in the COVID-19 epidemic. The Lancet Psychiatry. 2020;7(4):21. doi:10.1016/S2215-0366(20)30090-0).

15. Guy W. Clinical Global Impressions. ECDEU Assessment Manual for Psychopharmacology Revised. 1976 Rockville, MD: U.S. Department of Health, Education, and Welfare; Public Health Service, Alcohol; Drug Abuse, and Mental Health Administration; National Institute of Mental Health. pp. 218-222.

16. Hoven CW, Duarte CS, Lucas CP, Wu P, Mandell DJ, Goodwin RD. Psychopathology among New York City public school children 6 months after September 11. Arch Gen Psychiatry 2005; 62: 545-52.

17. Laor N, Wolmer L, Mayes LC, Gershon A, Weizman R, Cohen DJ. Israeli preschool children under Scuds: a 30-month follow-up. J Am Acad Child Adolesc Psychiatry 1997; 36: 349-56.

18. Imran N., Zeshan M., Pervaiz Z. Mental health considerations for children \& adolescents in COVID-19 Pandemic. Pakistan J of Medic Sci, 36 (COVID19-S4). 2020 https://doi.org/10.12669/ pjms.36.COVID19S4.2759.

19. Olness K., Mandalakas A., Torjesen K. How to Help the Children in Disasters. 2015. 4th ed. Health Frontiers, Kenyon, USA.

20. Steiner H, Shaw R. Psychiatric assesment and manegement of medically ill children. A Stoudemire, BS Fogel, DB Greenberg (EDS.) Psychiatric Care of the Medical Patient, second ed., UK, Oxford University Press, 2000, p. 1097-1110.

21. Tian F., Li H., Tian S., Yang J., Shao J., Tian C., Psychological Symptoms of Ordinary Chinese Citizens Based on SCL-90 During the Level I Emergency Response to COVID-19, Psychiatry Res, 2020, 288, https://doi.org/10.1016/j.psychres.2020.112992.

22. Jiao W., Y Wang L. N., Liu J., Fang S. F., Jiao F. Y., Pettoello-Mantovani M., Somekh E. (2020). Behavioral and Emotional Disorders in Children during the COVID-19 Epidemic. The $J$ al of Pediatrics. doi.org/10.1016/j.jpeds.2020.03.013. 